\title{
ADRAMATURGIA DE ROBERTO GOMES, DA CASA FECHADA À ABERTURA MODERNISTA
}

\author{
MARTA MORAIS DA COSTA*
}

A obra de Roberto Gomes (1882-1922) sobressai na lista do pequeno grupo de dramaturgos no período entresséculos que, à falta de melhor denominação, Tristão de Ataíde qualificou como Pré-Modernismo. ${ }^{1} \mathrm{Na}$ literatura, o limite final do período é claramente marcado pela Semana de Arte Moderna de 1922. Em relação ao teatro, contudo, há divergências quanto aos limites cronológicos abrangidos pelo prefixo pré, antes definidor de uma época de transição do que qualificativo de uma determinada estética predominante. Edwaldo Cafezeiro e Carmem Gadelha compreendem Pré-Modernismo tendo como limites os anos que vão da "morte de Artur Azevedo (1908) e anterior à Semana de Arte Moderna (1922)". ${ }^{2}$ Sabemos que Sábato Magaldi data o início do teatro moderno brasileiro da estréia de Vestido de noiva, de Nelson Rodrigues, em

* Professora Sênior, atuando no Programa de Mestrado e Doutorado em Estudos Literários da UFPR. Este artigo retoma a análise crítica constante da introdução ao Teatro Completo de Roberto Gomes, editado pelo Inacen em 1983. E o faz reformulando o texto, acrescentando informações e revendo algumas afirmativas do texto anterior.

1 ATAÍDE, T. de. Contribuição à história do Modernismo. O Pré-Modernismo. In: BOSI, A. A literatura brasileira - O Pré-Modernismo. São Paulo: Cultrix, 1966. p. 11.

2 CAFEZEIRO, E.; GADELHA, C. História do teatro brasileiro: de Anchieta a Nelson Rodrigues. Rio de Janeiro: Editora UFRJ; Funarte, 1996. p. 342.

3 MAGAldi, S. Panorama do teatro brasileiro. 4. ed. São Paulo: Global, 1999. 
COSTA, M. M. da. A dramaturgia de Roberto Gomes,...

$1943,{ }^{3}$ isto quer dizer, o Pré-Modernismo estender-se-ia até essa data. Assim como os dois fatos (a Semana e Vestido de noiva) não implicaram imediata adesão de todos os escritores, dramaturgos e artistas, também o teatro teve textos e espetáculos que permaneceram na velha estética. Além do mais, o teatro, diferentemente da literatura, para que possa efetivamente contar como marco de uma nova estética, precisa combinar a inovação dramatúrgica com igual comportamento no palco. Essa combinação de componentes postergou o aparecimento do espetáculo moderno, de vez que, em alguns experimentos, eles apareciam isolados, como foi o caso de $O$ Rei da Vela, de Oswald de Andrade, de 1937, sem montagem alguma na época em que foi escrito. Outras experiências modernistas foram acontecendo no período posterior a 1922, com Flávio de Carvalho e O Bailado do Deus morto, em 1932. Somos do parecer, e é o marco que adotaremos, que o Teatro de Brinquedo, de Álvaro Moreyra e o espetáculo Adão, Eva e outros membros da família, de 1927, pode ser adotado como início do Modernismo no palco, de que Vestido de noiva será o ápice.

Polêmicas cronológicas à parte, podemos dizer de Roberto Gomes que foi um autor de fina sensibilidade poética, afinado com a tendência francesa de uma dramaturgia interiorizada, de minúcias, de sugestividade e de pouca eloqüência. Sua obra ganha realce entre os escritores contemporâneos, que permaneciam voltados ao realismo, com peças recheadas de cenas de embates violentos entre personagens ou devotadas ao gênero cômico-musical, tão bem representado pelas revistas e burletas, herdadas do século XIX.

A diferença entre eles se deve, sobretudo, à relação dialética BrasilEuropa, uma das marcas características da cultura brasileira do período. No caso de Roberto Gomes, a influência mais forte e duradoura provém da França, a que estava ligado por laços sangüíneos (sua mãe era francesa), educacionais (sua formação escolar se deu naquele país) e cultural (a língua serviu de forte amarra para as idéias que foi cultivando sobre a arte teatral, a partir da leitura de teóricos e dramaturgos, como Maeterlinck e Bataille). Como resultado, sua dramaturgia apresenta tênue parentesco com o teatro brasileiro da época, apesar do autor aqui ter nascido e vivido a quase totalidade de seus quarenta anos de existência. Em Roberto Gomes, a profunda nostalgia e a contínua sensação de exílio da França bem-amada foram mais do que uma conduta da moda. O parisianismo, doença intelectual de tão fácil contágio quanto a febre amarela no Rio de Janeiro no início do século XX, encontrou na figura de Roberto Gomes terreno fértil para germinar e produzir.

Creio que foi em função da maneira diferente de construir as personagens e a ação dramática, próximas do teatro francês e belga, que a obra de Roberto 
Gomes, destoando das expectativas do público ainda restrito que freqüentava os teatros cariocas, foi marginalizada e quase esquecida por um longo período.

A passagem do século no Brasil constituiu-se num período de grandes convulsões sociais e culturais que refletiam com freqüência o movimento histórico europeu. O Simbolismo e o Parnasianismo afirmavam-se enquanto caminhos literários válidos e influenciadores. Rui Barbosa representava a crença na correção gramatical enquanto critério fundamental para a avaliação de qualquer texto. Coelho Neto e Olavo Bilac realizavam na prática este ideário, convertendo-se em estrelas de primeira grandeza na constelação intelectual que ditava normas à literatura. As duas primeiras décadas do século XX traziam, porém, ares de renovação e apresentavam posições contraditórias no seio da intelectualidade atuante. Se, por um lado, a forte corrente francesa influenciava até os futuros modernistas (Oswald de Andrade e Menotti Del Picchia escrevem em parceria duas pequenas peças de teatro em francês: Mon coeur balance e Leur âme, em 1916), por outro, vicejava o ideário nacionalista no rastro de Lima Barreto e seu Policarpo Quaresma e de Monteiro Lobato, na conversão do Jeca Tatu em símbolo do homem brasileiro interiorano.

Um novo Brasil, menos cosmopolita, recatado e polido, mais agressivo e selvagem, estava surgindo lentamente para a literatura. A publicação de $O s$ Sertões (1902), de Euclides da Cunha, desencadeia o interesse e a atuação de romancistas e contistas na busca da realidade escondida nas regiões afastadas das capitais. Assim, somaram-se à monumental obra de Euclides da Cunha, Lendas do Sul (1913), de João Simões Lopes Neto, Lendas e tradições brasileiras (1916), de Afonso Arinos, Tropas e boiadas (1917), de Hugo de Carvalho Ramos, Urupês (1918), de Monteiro Lobato - obras que procuravam contribuir para o delineamento do perfil de um país que, apesar de quatro séculos de vida, desconhecia a si mesmo.

A primeira década do século XX assistiu à implantação da jovem República. A belle époque dominava os salões, os costumes, a moda e a arquitetura de uma sociedade burguesa que se afirmava definitivamente. $\mathrm{O}$ progresso parecia resolvido a habitar a nação dos brasilíndios. As máquinas chegaram, e, com elas, o inevitável contingente de operários que as moviam. Os congressos operários, greves e reivindicações também se iniciaram com o século. A agitação social dinamizou os noticiários dos jornais e impulsionou a alteração da pacata vida burguesa de saraus, concertos e bailes, além de provocar mudança nos valores que regiam a sociedade. São Paulo emergiu como a capital econômica da República.

A sociedade carioca também recebia os influxos do que, à época, considerava-se civilização. O Rio de Janeiro remodelou-se sob a gestão do 
prefeito Pereira Passos (sob o lema impositivo "O Rio civiliza-se") e a febre amarela foi exterminada através da campanha de Osvaldo Cruz. A capital do país contrastava o gosto aristocrático, a elegância e o sorriso dos freqüentadores do refinado comércio da Rua do Ouvidor com a miséria dos cortiços. A arte, sobretudo a literatura, tanto se expressava segundo as normas francesas quanto procurava um acento nacional, trilhando os caminhos do regional geográfico e humano. O teatro, dominado pelo constante fluxo de companhias francesas, espanholas e portuguesas, tentava corajosamente encontrar um lugar próprio com temário e tratamento nacionais, como na peça Flores de sombra (1916), de Cláudio de Souza, no grande sucesso de Juriti (1919), de Viriato Correia ou em Onde canta o sabiá (1921), de Gastão Tojeiro.

O teatro brasileiro já vinha se transformando, porém lentamente. O começo do século intensificou a constatação de que a cena brasileira sofria de profunda anemia. Em 1908, companhias, autores e salas de espetáculos compunham uma tríade numericamente pequena. O público, proporcional à dimensão do Rio de Janeiro do tempo, era refinado e poliglota, apreciava sobremaneira o teatro europeu, não deixava de prestigiar os espetáculos das companhias estrangeiras e, sobretudo, desprezava o autor nacional que não escrevesse revistas ou comédias.

A polêmica de Artur Azevedo com o ator Cardoso da Mota, ${ }^{4}$ em 16 de maio de 1904, a respeito da depravação e decadência de nosso teatro, causadas pela moda da revista e da burleta, continuava verdadeira quando se referia ao binômio palco/público.

Artur Azevedo, injustamente acusado de causador desse caos, foi, na realidade, um grande homem de teatro da época. Sua iniciativa, entusiasmo e trabalho prestigiaram o autor nacional em dois importantes eventos: o Teatro da Exposição Nacional, em 1908, e a inauguração do Teatro Municipal do Rio de Janeiro, em 14 de julho de 1909. O espetáculo dessa inauguração teve caráter exclusivamente brasileiro, embora a data escolhida tenha sido a da Queda da Bastilha. A música de Francisco Braga e Carlos Gomes, o discurso de Olavo Bilac, a comédia em um ato, Bonança, de Coelho Neto e ópera em uma ato, Moema, de Delgado de Carvalho compuseram o programa nacionalista do evento.

Foi uma vitória brasileira diante dos padrões de espetáculo da época. No entanto, o palco do Teatro Municipal foi ocupado a seguir pela Companhia Dramática Francesa de Réjane até o mês de agosto, sendo substituída pela

4 MAGALDI, op. cit., p. 144. 
Companhia Italiana de Nina Sanzi! O hábito fazia o monge no teatro brasileiro da época.

O Rio de Janeiro, termômetro cultural do Brasil, refletia o descaso com que era tratada a arte de representar, desde que o palco estivesse - ou pretendesse estar - ocupado por elencos e dramaturgia nacionais. São raras as companhias formadas por atores brasileiros, e quase todas mambembes, que " representavam de tudo, exploravam qualquer gênero, em condições precárias e adversas, exibindo-se em teatros improvisados", constituindo, antes de tudo, um "bando de famélicos saltimbancos, que a fama da figura principal sustentava". ${ }^{5}$

O repertório era constituído pelo drama realista, por revistas, mágicas e burletas. Os autores, geralmente "literatos transformados em comediógrafos", faziam a literatura dramática ser muito mais livro e leitura do que espetáculo. A dicção e o diálogo tinham, por isso, a inconfundível marca da retórica literária.

Isso não impedia o grande movimento teatral das companhias estrangeiras, formando - ou seria melhor, deformando? - o gosto de público, determinando-o, influindo na maneira de representar, na dicção dos atores, nos temas e seu tratamento e, até mesmo, no poliglotismo do palco.

A crítica teatral era pobre, quase inexistente, e " não havia senão, em um ou outro jornal, de cuja redação fazia parte um maluco de teatro, seção teatral fixa". ${ }^{7}$ Roberto Gomes, ele mesmo, exerceu a crítica teatral e musical em A Notícia e $O$ Imparcial. Na análise dos espetáculos em cartaz, demonstrava o domínio das novas idéias de um teatro intimista, sugestivo e de ação rarefeita, na esteira do pensamento de Maeterlinck. ${ }^{8}$ Também reconhecia o valor da dramaturgia que retratava as grandes comoções da alma humana, ao se confrontar com o amor não correspondido, o desespero, a morte, seguindo os conceitos expressos por Henri Bataille. ${ }^{9}$

Manifestando a posição polimórfica desse período de transição das artes rumo às vanguardas, Roberto Gomes, em conferência intitulada Arte e gosto artístico no Brasil, proferida em 10 de outubro de 1912 na Biblioteca Nacional, no Rio de Janeiro, demonstra seu conhecimento dos movimentos artísticos que eclodiam na Europa na época:

5 NUNES, M. 40 anos de teatro. Rio de Janeiro: Serviço Nacional de Teatro, 1956. v. 1. p. 13.

6 Ibid., p. 14.

7 Id.

8 BERTHOLD, M. História mundial do teatro. Tradução de: M. P. Zurawski; J. Guinsburg; S. Coelho; C. Garcia. São Paulo: Perspectiva, 2000. p. 466.

9 BATAILlE, H. Écrits sur lê théâtre. Paris: G. Crés, 1917. 
COSTA, M. M. da. A dramaturgia de Roberto Gomes,...

Como vedes, manifestam-se hoje livremente e fraternizam as tendências mais diversas. Restos de romantismo, surtos de naturalismo, reflexos de pré-rafaelismo, audácias de impressionistas, que têm a faculdade de ver todas as coisas verdes, escarlates ou roxas, e de que nós não devemos rir, porque todo excesso contém sem dúvida uma parcela de verdade. (...) Os senhores futuristas afirmam que estão no seu perfeito bom senso, e eu o creio. Talvez vejamos no próximo "Salon" alguns quadros cubistas. O que parece é que os senhores futuristas confundem uma arte com outra e querem obrigar a pintura a exprimir o que só pertence à música. Um grupo de literatos já tentou, é verdade, em uma ocasião, estabelecer laços estreitos entre a poesia, a pintura e a música. Todas as vogais tinham uma cor: A era branco, E era verde, $\mathrm{O}$ vermelho; $\mathrm{O}$ era a trompa, E era a flauta etc. Mas a orquestra parece que deu um resultado um tanto cacofônico e acho preferível tratar da música isoladamente. ${ }^{10}$

A atividade dramática de Roberto Gomes, entre os anos 1910 e 1921, esteve, portanto, marcada pelas contradições de seu tempo. A companhia que representou sua peça Ao declinar do dia..., em 1910, era luso-brasileira e a temporada não agradou. Dois anos depois, porém, na primeira representação de $O$ canto sem palavras, a situação mudou porque os atores da peça formavam "a primeira companhia brasileira que ocupou o Teatro Municipal, pretendendo restituílo à sua finalidade, [a qual] foi organizada por Eduardo Vitorino, aceitando o prefeito Bento Ribeiro a proposta, cedendo à cerrada campanha da imprensa", conforme documenta Mário Nunes. ${ }^{11}$

Trabalhar por um teatro brasileiro era participar de uma Guerra Santa, tão poderosa era a força do hábito de assistir aos elencos e peças estrangeiras e tamanho era o descrédito do público em relação ao autor brasileiro. Descrédito que continuava, mesmo em período posterior à Semana de Arte Moderna. Em 1923, quando da estréia de Berenice, de Roberto Gomes, a imprensa afirmou que a pouca afluência do público carioca deveu-se ao fato de a peça ter sido escrita por um brasileiro. Foi a acusação divulgada nas páginas da Revista da Semana, por Rosalina Coelho Lisboa e no jornal A Rua, por Alberto de Queiroz.

10 apud MARTINS, W. História da inteligência brasileira (1897-1914). São Paulo: Cultrix; Edusp, 1977-1978. v. 5. p. 522.

11 NUNES, op. cit., p. 45. 
Gradualmente, houve melhora na qualidade dramática, no número e qualificação das companhias teatrais: em 1919, Mário Nunes calculou que já existiam, no Rio de Janeiro, 18 companhias mistas ou nacionais em atividade.

Foi nesse contexto que Roberto Gomes exerceu sua atividade intelectual. Como jornalista, ele escreveu, desde 1909, em A Gazeta de Notícias: primeiramente sob o pseudônimo de Bemol e, a partir de 26 de agosto de 1911, assinou o próprio nome nas críticas da seção Crônica musical. Também foi articulista, crítico musical e teatral em A Notícia e O Imparcial.

Afora o trabalho regularmente remunerado como professor, inspetor escolar e jornalista, escreveu e publicou peças de teatro, poemas, contos e conferências. Dos primeiros, salientamos Alanguissement, Le soir dans la chambre e Le promeneur solitaire, todos em francês, publicados na Revista Souza Cruz, em agosto de 1904. Em 1. ${ }^{\circ}$ de janeiro de 1915, a famosa revista Ilustração Brasileira publicou o conto Os camondongos.

$\mathrm{Na}$ esteira da moda das conferências que se alastrou no início do século no Rio de Janeiro e em outras cidades brasileira, Roberto Gomes falou sobre Liszt, Grieg, Zola (1902), Os cachorros e o amor canino (1907), A arte e Arte e gosto artístico no Brasil (ambas de 1912) e sobre Maurice Maeterlinck (1918). A revista Ilustração Brasileira publicou, em 1922, o último estudo do dramaturgo carioca: uma longa e minuciosa análise da obra de Henri Bataille.

Exímio pianista, foi também ator amador em espetáculos montados na cidade de Petrópolis e na representação de sua peça Sonho de uma noite de luar, em 1916, no Rio de Janeiro.

Mas foi sobretudo pelo que escreveu para o palco que o nome de Roberto Gomes ficou registrado em nossa história intelectual. Sua dramaturgia compreende nove peças: Le papillon (1897-1898), Ao declinar do dia... (1910), O canto sem palavras (1912), A bela tarde (1915), O sonho de uma noite de luar (1916), Berenice (1917-1918), Ojardim silencioso (1918), A casa fechada (1919) e Inocência (1915-1921). Quatro delas foram vertidas para o francês: Ao declinar do dia..., Berenice, A casa fechada e Inocência.

A única comédia de sua obra, Le papillon, nunca foi traduzida para o português. Trata-se de um texto escrito na juventude, com um enredo fraco e sem originalidade no tratamento temático. Gastão e Teresa formam o casal apaixonado que não se pode unir porque o pai da moça, um entomólogo fanático, só aceita como genro um rapaz que seja colecionador e amante das borboletas, como ele. E Gastão não tem a menor inclinação para colecionar insetos. Aparece, então, outro pretendente que atende os requisitos do pai. Para decidir, o pai da moça estabelece como condição que o candidato a futuro genro lhe traga um 
espécime da rara borboleta “Flambe”. Um amigo de Gastão ajuda-o, comprando uma borboleta movida a corda, que é a reprodução exata do inseto natural. Gastão consegue casar-se após várias peripécias, e, na hora do enlace, a borboleta artificial projeta-se no espaço por um aparente descuido do rapaz.

Os diálogos possuem uma certa leveza, mas o cômico apóia-se em recursos muito explorados, como a troca de personagens, esconderijos inusitados, quedas, fugas e disfarces. Nada faz prever, nesta primeira peça, a tônica característica do teatro de Roberto Gomes. O próprio autor renega esse texto, indicando Ao declinar do dia... como o início de sua obra dramática.

O conjunto das peças de Roberto Gomes apresenta unidade de idéias a respeito da função e da configuração do teatro do início do século, e reiteração de situações, personagens, espaço e linguagem dramática.Trata-se de um teatro impregnado por uma decadentista e refinada visão do mundo e dos homens, expressa poeticamente. Há nessas peças uma evidente preocupação com a psicologia em detrimento de peripécia ou da sociologia. A sensação deixa em segundo plano a ação, o silêncio se sobrepõe ao ruído e, até mesmo, à fala, e a noite e o crepúsculo são mais sugestivos e densos do que a luz do dia.

Acreditando na alta importância do sentimento, do sofrimento e da solidão para a compreensão do ser humano, Roberto Gomes enveredou pela forma francesa do teatro da paixão, cujos grandes nomes, na época, eram Henri Bataille, Porto Riche e Bernstein. Esse teatro tem como objetivo realizar, através da ação dramática, uma cirurgia na sociedade burguesa, expondo ao leitor os órgãos apodrecidos pela corrupção e egoísmo, pela hipocrisia e ambição, e, principalmente, apresentar o coração devorado por paixões inconfessáveis, que conduzem sempre à dor mais funda e ao desespero. As personagens femininas, geralmente volúveis e ambiciosas, são heroínas à beira do abismo, sucumbindo à tentação da carne por amor, tédio ou ambição. As personagens masculinas personificam o protótipo do burguês bem sucedido ou do aspirante a essa posição. Ao endeusar o dinheiro e a fama, não medem a moralidade de suas ações e conseguem, com cinismo, atingir os objetivos traçados, deixando atrás de si um rastro de destruição, descrença e dor. O teatro da paixão expõe, sem hesitação, as situações mais cruas, como o suborno, o adultério, a chantagem e a morte. Procura, em momentos de profunda emoção, analisar detalhadamente o comportamento e as reações do ser humano:

Denominamos verdades exteriores as aparências exatas e proporcionais das coisas, o que é tangível e enunciado na natureza; 
é assim tanto a linguagem falada quanto o espetáculo cênico, seu amálgama. Isto é, a própria estrutura do teatro. Denominamos verdades interiores o segredo dos seres, o que se movimenta dentro do indivíduo e que ele não exprime diretamente; são assim as esferas inconscientes dos indivíduos. ${ }^{12}$

Trata-se de uma dramaturgia de grande contundência e de alto valor documental porque denuncia a violência e a hipocrisia das relações pessoais na sociedade do tempo. Apresenta uma visão desmascarada da verdade burguesa: os vencedores são os fortes, e por trás de suas vitórias não há glória nem honra. Os seres que povoam esse universo possuem no coração e na cabeça abismos de corrupção, que dirigem seus atos e paixões. É um teatro que retrata impiedosamente a mesquinhez, o vazio, o tédio e a hipocrisia da sociedade decadente que preparou a Primeira Grande Guerra. Nele, o troco miúdo do cotidiano confronta-se com a moeda de ouro do amor e, por vezes, a corrói, destrói e subjuga.

Na obra de Roberto Gomes, o realismo do teatro da paixão foi atenuado pela influência de outra dramaturgia, a do teatro do escritor belga Maurice Maeterlinck. Foi somente em 7 de agosto de 1918 que o público carioca pôde assistir à primeira montagem de uma peça do autor belga: tratava-se de sua obraprima, Pélleas et Mélisande. Roberto Gomes, porém, já conhecia e admirava essa dramaturgia muito antes da data. Pôde, por isso, analisá-la e julgá-la na conferência que proferiu momentos antes do espetáculo no palco do Teatro Municipal do Rio de Janeiro.

O tema fundamental do teatro de Maeterlinck é o amor puro, espiritualizado, apaixonado, absoluto, avassalador e inesquecível. Os amantes, enredados e impotentes, sofrem contínua e profundamente e são aniquilados pelo destino cruel. Dominados por um amor impossível, encontram na morte a única saída e alívio para a Dor. A caminhada rumo ao fim inexorável é feita em silêncio, pois a dor verdadeira não se expressa pela palavra, desgastada e limitada por natureza. Expressa-se muito mais pelo gesto, pelo soluço, pelo gemido e, até mesmo, pelo silêncio. A linguagem da comunicação trivial e cotidiana é banida. Maeterlinck privilegia a musicalidade do verso, a sugestão da metáfora, a ambigüidade da parábola, que devem ser sussurrados, mais do que proclamados em bom som. As personagens, sugeridas pelo manto diáfano da poesia musicalizada e metafórica, tornam-se visões e sonhos.

12 BATAILLE, op. cit., p. 127. Tradução livre, sem grifos no original. 
COSTA, M. M. da. A dramaturgia de Roberto Gomes,...

Roberto Gomes tentou - e por vezes conseguiu com êxito - amalgamar a crueza do bisturi francês com a lira poética belga.

Bataille afirmava que "o amor é o grito de revolta contra o vazio da vida" ${ }^{13}$ Fiel a esse preceito e ao tratamento maeterlinckiano dessa temática, o teatro de Roberto Gomes está construído sobre o tema exclusivo do amor. É em torno dele que giram as personagens, seus desejos, lutas e, freqüentemente, sua derrota.

Os costumes e comportamento da sociedade carioca e fluminense formam o pano de fundo necessário ao enquadramento dos protagonistas em tempo, espaço e contexto social definidos.

Dado que seu teatro ainda padece de um certo desconhecimento, propomos uma rápida descrição de alguns de seus textos para que funcione com uma espécie de enquadramento para a análise mais minuciosa da peça $A$ casa fechada.

Em Ao declinar do dia..., de 1910, Laura está casada com Viriato, mas seu casamento já apresenta grande desgaste. Ambos vivem a solidão a dois. $\mathrm{O}$ marido da protagonista está muito doente e, acamado, permanece no leito. Ao crepúsculo, a chegada de um visitante inesperado, Jorge, antigo amor da moça, traz à cena todo o romance vivido no passado. Ante a possibilidade da viuvez, como se as amarras sociais se afrouxassem e a lembrança dos momentos anteriores se tornasse imperiosa, os dois beijam-se. Ouve-se um baque surdo. Viriato está morto no corredor frente ao quarto. Na impossibilidade de definir se o beijo apressara a morte do marido, Laura recusa o amor de Jorge, que parte definitivamente para longe da felicidade. A impotência de Laura diante da morte do marido e a impossibilidade de definir-lhe a causa exata conduzem ao sofrimento e à percepção do quanto é frágil e efêmera a felicidade humana.

O canto sem palavras, de 1912, mostra o drama de Maurício, que, aos 58 anos, se apaixona por Queridinha, sua afilhada, ainda adolescente com 17 anos, filha da mulher a quem amara na juventude e que, ao morrer, incumbira-o da tutela da criança. Ante a confissão da moça de que está apaixonada e o pedido de permissão para casar-se, Maurício revolta-se e recusa-se a autorizar o enlace. Em cena, aparece Hermínia, atual amante de Maurício, que abre seus olhos para a paixão que sente por Queridinha. Sem confessar-se, sofrendo, ele decide abandonar o Brasil e parte em viagem para a Europa, sem data de volta, na companhia de Hermínia. Enquanto isso, Queridinha prepara-se para o casamento, sem desconfiar da paixão que despertara no tutor.

13 BATAILLE, $\mathrm{H}$. La femme nue. In: Ecrits sur le théâtre. Paris: Georges Crès, 1917. p. 192. 
A peça é um drama sobre a descoberta e posterior perda do amor, sobre o sofrimento e a amargura, sobre o desespero calado e solitário, enfim, sobre uma paixão crepuscular, numa atmosfera de delicadezas e renúncia.

A bela tarde, de 1915, registra, em instantâneos de leve humor e sutileza, o cotidiano de uma família classe média no Rio de Janeiro do começo do século. Papai diverte-se em cuidar das plantas e ler seu jornal diário. Mamãe, típica figura matriarcal conservadora, cuida do bordado e da educação da filha, Nicota, enquanto exerce o diz-que-me-disse de toda a vizinhança com igual afinco e rara sensibilidade. O tio, cinqüentão, cético e infeliz, é a personagem mais rica da peça: seu ceticismo e amargura são reflexos da sensibilidade ferida, de sentimentos amorosos espezinhados. Abandonado por aquela que poderia ter sido seu derradeiro amor, sente chegar o crepúsculo da vida com a amargura dos derrotados e na solidão dos vencidos.

O sonho de uma noite de luar, no ano seguinte, apresenta Cristiano, um artista, já maduro, que dialoga em cenas de pura ilusão com Edel, a quem amara quando tinham ambos quinze anos. Na noite em que volta tarde à casa, depois de um compromisso social, recebe a visita de uma mulher que, ao primeiro olhar não reconhece. É Edel, madura, que lhe propõe retomar o amor da juventude. Ele recusa pois sonha um amor mais perfeito. $\mathrm{O}$ texto termina quando a Edel real é afastada e se vai, enquanto Cristiano permanece enlevado com a ilusão da presença do amor adolescente, recuperado pelo sonho.

A ação dramática de Berenice inicia com a protagonista cercada de admiradores, prontos a sacrificar tudo por ela. Mas a todos afasta e recusa. Seu coração prepara-se para viver, provavelmente, a última paixão de sua vida, Flávio Orlando, pianista talentoso e pobre. Por ele, ela ignora diferenças sociais e de idade. O texto dedica-se a estudar a trajetória dessa paixão rumo ao abandono e ao suicídio da protagonista. Berenice, apesar dos exageros ao gosto da época, é um texto marcante do teatro da paixão na dramaturgia brasileira.

O jardim silencioso, de 1918, é um texto de alta poeticidade a respeito dos desencontros humanos. É a descoberta da traição feminina, causada, sobretudo, pela solidão. O marido vem a descobrir a infidelidade no dia em que sua esposa, atrasada para a comemoração do aniversário de casamento, é assassinada pelo amante. As informações vão chegando aos poucos ao público e ao protagonista, até a revelação final. A peça gira em torno de uma protagonista que não aparece em cena: ela é toda silêncio.

Inocência, adaptação da obra homônima do Visconde de Taunay, foi resultado de um trabalho de longo fôlego: sua composição aconteceu entre 1915 e 1921. Roberto Gomes enfatiza no texto dramático o tom trágico e fatalista do 
COSTA, M. M. da. A dramaturgia de Roberto Gomes,...

amor de Cirino e Inocência, cercado de cenas de grande sutileza, mistério e destinação trágica.

Apesar das constâncias temáticas, de personagens e de ambiência dramática, é A casa fechada, texto finalizado em 23 de julho de 1919, conforme atesta o manuscrito original, que apresenta a mais elaborada e avançada concepção dramatúrgica.

A peça retrata uma cidade do interior, abalada pela notícia de que uma de suas figuras mais conhecidas e honestas, Maria das Dores, fora surpreendida em flagrante adultério pelo próprio marido, Matias, que a agredira e expulsara de casa. Os habitantes da cidade nada sabem de concreto a respeito do fato e, com curiosidade, reúnem-se em frente da casa fechada de Maria das Dores à espera dos acontecimentos. Enquanto isso, tecem conjeturas e exprimem opiniões contrárias à adúltera, aguardando a chegada do barbeiro Geraldino, que afirmava ter visto tudo. Mas as informações que ele presta ao chegar estão distorcidas pelo sadismo, morbidez e inveja que o dominam, assim como às outras personagens, exceção feita ao Mendigo e à D. Eudóxia, chefe da agência de Correio. Estes tomam o partido da adúltera. Ao final da peça, a dúvida sobre o que realmente aconteceu persiste. A única certeza é a partida de Maria das Dores no trem das dezoito horas, abandonando, por exigência do marido, o lar e os filhos. ${ }^{14}$

O realismo do enredo e da observação factual e psíquica das personagens é substituído pela técnica polifônica do ponto de vista. O leitor vê-se pouco a pouco envolvido pela ação dramática de tal forma que, de repente, descobre-se tão participante quanto as personagens, integrando-se ao desenrolar da trama, elaborando também hipóteses para compor a cena central da descoberta do adultério.

A multiplicidade de pontos de vista altera o enredo tradicional, a tal ponto que o adultério de Maria das Dores, suposto foco temático principal, é obscurecido pela curiosidade (tanto do leitor quanto das personagens) e pela revelação, através da fala e dos comportamentos, de naturezas interiores insuspeitadas. As personagens, que cercam a casa da adúltera, observam a dor alheia. E é exatamente essa observação que desencadeia confidências e revelações e que motiva a exteriorização das mágoas recalcadas, do sadismo, da compaixão, dos preconceitos, da inveja e da maledicência. Por isso, as personagens periféricas acabam por constituir-se no centro do espetáculo.

O fundamental no texto é a escolha do ponto de vista organizador do conflito. O leitor apreende uma tessitura dramática em que, colocados lado a

14 Adotaremos a seguinte edição crítica da peça: COSTA, M. M. da. Teatro de Roberto Gomes. Rio de Janeiro: Inacen, 1983. p. 331-347. 
lado com as personagens, observa e analisa a situação proposta como um enigma, de que ignora a solução e até mal conhece os elementos que o formam. O incidente da noite da descoberta do adultério só é conhecido através da versão pessoal de uma testemunha ocasional. As pessoas, diretamente envolvidas no fato, são apenas seres de palavras: não estão presentes em cena Matias, o marido, e, muito menos, o Outro inominável. Maria das Dores é construída por vozes contraditórias e se tem dela apenas uma visão fugaz ao final do drama, quando passa silenciosa rumo à estação de trem.

Mas nem essa visão contribui para elucidar a verdadeira história do adultério. Apenas ao final da peça é que o leitor compreende que o tema central do texto é a dor de estar vivo. A vida, com acasos e tragédias, é que constitui o enigma. E no afã de decifrá-lo, é o próprio homem que acaba se revelando e descobrindo.

A casa fechada procura decifrar o enigma da existência, do destino e do acaso. Chega à conclusão, porém, que o ser humano é pequeno e ignorante: "Deus é que sabe...", afirma o Mendigo. O erro está dentro das pessoas que "não sabem ver".

A dor e a solidão de Maria das Dores não são verdadeiramente compreendidas. Ela é a sombra, a marginal, o ser humano a cumprir um destino de isolamento e incompreensão. Por isso, cresce no texto o tema do silêncio, manifesto, sobretudo, na quase total ausência de Maria das Dores, e de sua passagem muda pelo palco. O silêncio representa no teatro de Roberto Gomes, no teatro simbolista em geral e, em particular, no teatro de Maurice Maeterlinck, a forma de expressão do trágico cotidiano. O mistério da vida e da morte somente pode ser expresso pelo silêncio porque a palavra é limitada e limitadora; só a sugestão que nasce do espaço vazio entre as palavras é capaz de apreendê-lo.

Os seres esbatidos como sombras silenciosas e imóveis constituem, juntamente com o crepúsculo, uma das imagens mais apreciadas e freqüentes no teatro de Roberto Gomes. Esses seres de sombra, geralmente humildes e sábios, dispensam a retórica vazia e vibrante: pouco falam, mas expressam muito. $\mathrm{O}$ Mendigo, o Acendedor de Lampiões e Maria das Dores só precisam passar ou murmurar para deixar fundamente gravada no leitor, e, por extensão, no espectador, uma amarga compreensão da vida, do homem, da sociedade e sua ideologia. É essa posição amarga e desiludida que submete, derrota e freqüentemente aniquila o indivíduo.

A importância atribuída ao silêncio estabelece uma relação direta entre a ausência da palavra e a ausência da peripécia na ação dramática deste teatro. Roberto Gomes está muito mais interessado na reação que os acontecimentos 
COSTA, M. M. da. A dramaturgia de Roberto Gomes,...

provocam do que nos fatos em si. Por isso, quase tudo sucede fora do palco ou no passado. Em cena, só a reação, o reflexo no comportamento das personagens.

Em A casa fechada, as falas se mostram reflexivas, dinâmicas e fortemente interativas. É o pequeno grupo de representantes da cidadezinha do interior que se posiciona em relação à família e ao adultério. A ação nasce do interrelacionamento das personagens em cena, sem retórica inflamada e num jogo contínuo de desvendamento de mecanismos psíquicos de autodefesa e de afirmação, como em Ritoca, no Boticário, em Geraldino e no Pescador.

A narração é evitada neste texto dialogal, e quando surge, como a de Geraldino ao contar o que pode ter sucedido na noite anterior, ou como a do Pescador em sua parábola, tem a função de história exemplar, demonstrando o comportamento sádico e violento dos maridos traídos. A narração das cenas de sangue motivam prioritariamente o estudo das diferentes reações dos ouvintes e, por seu exagero, deformam expressionisticamente os fatos.

O espaço é outro componente importante. Dos textos dramáticos de Roberto Gomes, este apresenta um uso particular do palco. Somem os tão freqüentes espaços de intimidade. Seu teatro vai à rua, deixa a cidade grande para internar-se na comunidade interiorana. Entre os habitantes, prefere escolher os tipos que não sejam regionais para não sugerir apenas uma cor local romântica ou pitoresca. Persegue com interesse o ser humano camuflado atrás de profissões e, por isso, aparentemente sem individualidade. Poucos têm um nome próprio, são seres um tanto coletivos: o Boticário, a Agente de Correio, o Pescador etc. A ação vai se encarregar de provar que as máscaras profissionais são insuficientes para esconder o ser humano imperfeito e problemático.

O texto dramático multiplica-se em espaços significativos, caracterizados simultaneamente pelo dual e opositivo. A rua, espaço aberto e social, opõe-se à casa, fechada e individual. Este primeiro nível amplifica-se em pares contrários cada vez mais extremos: a conversa/o silêncio; o movimento/o estático; a tentativa de decifração/o enigma; os outros/a solitária; o múltiplo/a única e a suposição/ a verdade.

A casa apresenta-se como símbolo de intimidade, de silêncio e de falsa paz. Ela é a representação da alegria, do drama e do sofrimento de Maria das Dores: na época feliz, com flores; na desgraça, sem elas e fechada. A ausência de Maria das Dores no palco é apenas corporal, porque a casa torna-se índice de sua presença.

O tempo em que decorre a ação dramática está limitado pela chegada do trem à estação. Portanto, o conflito apresenta-se concentrado em, aproximadamente, uma hora, necessária para que as personagens possam chegar 
à cena, falarem de modo a expor pouco a pouco suas verdades interiores e preparar a passagem de Maria das Dores. Arranjado dessa forma, o tempo da ação dramática equivale ao tempo da encenação, numa simbiose intensificadora dos sentidos e verossimilhança do texto.

A combinação de uma visão mais crítica e desvendadora das ações humanas, o uso do dialogismo como prismatização do real, o abandono do enredo de intensidade dramática para o de densidade psicológica, o silêncio permeando significativamente o diálogo cênico e a sincronia entre o tempo dramático e o tempo cênico tornam $A$ casa fechada um texto singular dentro da dramaturgia brasileira. E, em relação ao teatro pré-modernista, um indicador de novos caminhos dramatúrgicos.

O conjunto dessas qualidades faz, com todos os méritos, sobressair a posição de Roberto Gomes em sua época, garantindo ao drama A casa fechada um lugar na posteridade e em nossa contemporaneidade.

\section{RESUMO}

A obra dramática de Roberto Gomes (1882-1922) representa um momento ímpar da dramaturgia brasileira, pois exemplifica a tensão dialética criada pela relação entre as culturas francesa e brasileira, tratando a realidade com um olhar que ultrapassa seu tempo histórico. Predomina em seus textos uma poética do silêncio aliada à investigação profunda do sofrimento humano, advindo da destinação trágica a que os homens estão submetidos, principalmente nas relações amorosas. Serve de base teórica desse teatro o pensamento de Maeterlinck e de Henri Bataille. Destaca-se no conjunto de peças, pela contemporaneidade do tratamento dramatúrgico, o texto A casa fechada, de 1919.

Palavras-chave: Teatro de Roberto Gomes, Teatro Pré-Modernista, história do teatro brasileiro.

\section{RÉSUMÉ}

L' oeuvre dramatique de Roberto Gomes (1882-1922) est représentative d'um période singulier de la dramaturgie brésilienne parce qu'elle exemplifie la tension dialectique créé par la rélation entre les cultures française et brésilenne et pour exposer la réalité à partir d'une perspective qui excède son temps historique. Dans ses textes prédomine une poétique du silence, liée à l' investigation profonde de la douleur humaine, fruit de la 
COSTA, M. M. da. A dramaturgia de Roberto Gomes,...

destination tragique à laquelle sont soumis lês êtres humains, surtout à cause des rélations amoureuses. La pensée téorique de Maeterlinck et de Henri Bataille est la fondation principale de ce théâtre. A casa fechada, pièce de 1919, s' impose dans l'ensemble des textes dramatiques de l'auteur par la contemporaneité de l'écrite dramaturgique.

\section{REFERÊNCIAS}

BATAILLE, H. Écrits sur lê théâtre. Paris: G. Crés, 1917.

BERTHOLD, M. História mundial do teatro. Tradução de: M. P. Zurawski; J. Guinsburg;

S. Coelho; C. Garcia. São Paulo: Perspectiva, 2000.

BOSI, A. A literatura brasileira - O Pré-Modernismo. São Paulo: Cultrix, 1966.

CAFEZEIRO, E.; GADELHA, C. História do teatro brasileiro:de Anchieta a Nelson Rodrigues. Rio de Janeiro: Editora UFRJ; Funarte, 1996.

COSTA, M. M. da. Teatro de Roberto Gomes. Rio de Janeiro: Inacen, 1983.

MAGALDI, S. Panorama do teatro brasileiro. 4. ed. São Paulo: Global, 1999.

MARTINS, W. História da inteligência brasileira (1897-1914). São Paulo: Cultrix; Edusp, 1977-1978. v. 5.

NUNES, M. 40 anos de teatro. Rio de Janeiro: Serviço Nacional de Teatro, 1956. 